\title{
On the composition of nutrients in wild and cultivated mushrooms
}

\author{
MATTI KREULA, MAIJA SAARIVIRTA and SIRKKA-LIISA KARANKO
}

\begin{abstract}
KREULA, M., SAARIVIRTA, M. \& KARANKO, S.-L. 1976: On the composition of nutrients in wild and cultivated mushrooms. - Karstenia 16: $10-14$.

The basic composition and the contents of amino acids and fatty acids and eight minerals of nine wild and two cultivated mushrooms were investigated. On a dry matter basis, the protein content of the mushrooms studied (Total N x 6.25) varied between $12 \%$ and $31 \%$, the fat content between $1.2 \%$ and $8.9 \%$ and the ash content between $5.7 \%$ and $12.8 \%$. The amount of essential amino acids (excluding Try) varied between $2.6 \%$ and $7.6 \%$ of the dry matter.

The fat content of the mushrooms, which in fresh mushroom is $0.2-0.5 \%$, was on the average $4.5 \%$ of the dry material. The fatty acid composition resembled the general composition of vegetable fats, because there was plenty of oleic and linoleic acid.

The mineral composition of the mushrooms studied was complex. It seems that they are good sources of $\mathrm{Cu}$ and fairly good sources of $\mathrm{Zn}$ as compared with other foodstuffs, provided that there are no remarkable differences in their availability.
\end{abstract}

M. Kreula, M. Saarivirta and S.-L. Karanko, Laboratory of the Foundation for Chemical Research, Kalevankatu 56 b, SF-00180 Helsinki 18, Finland

The present efforts to collect more effectively wild mushrooms and to process the mushroom crop into all-year foodstuffs has increased interest in the study of mushrooms. The present investigation deals with the nutrient composition of mushrooms and the possibilities to produce mushrooms by cultivation.

The digestibility of the protein of mushrooms was studied about 100 years ago by for example Sokolov (1870), Saltet (1885), Strohmer (1886), Mörner (1886) and Uffelmann (1887) (these cited in Rautavaara 1947). According to their studies the digestibility of mushroom protein varied between $41 \%$ and $79 \%$. At the beginning of this century Loewy et al. (1915, in Rautavaara 1947) obtained results showing a digestibility of up to $80 \%$ for mushroom protein. According to later studies by Lintzel (1943) the digestibility was considerably lower, varying between 17 and $46 \%$. The protein content of mushrooms calculated on a dry weight basis was $11-52 \%$; that of potato, used for comparison, being $8 \%$. The above studies represent earlier mushroom research which dealt with other nutritive factors than protein as well.

Besides the nutritional significance of mushrooms, scientists have always been interested in the poisonous compounds found in certain mushrooms and in their toxicological and pharmacological effects. One of the latest studies in this field is the dissertation work of Nieminen (1976) on the effect of the kidney poison of Cortinarius on rats.
In the laboratory of the Foundation for Chemical Research the amino acid, fatty acid and mineral contents of certain wild and two cultivated mushrooms have been studied. The results are tentative because of the small number of the samples.

\section{Materials and methods}

The wild mushrooms were collected from around Tampere in western Finland. The samples came to the laboratory predried, so that the dry matter content in the original samples is not known.

The mushrooms were predried using two methods: Boletus edulis, Albatrellus ovinus, Gyromitra esculenta, Craterellus cornucopioides, Cantharellus cibarius, Cantharellus tubaeformis and Armillariella mellea at $50-55^{\circ} \mathrm{C}$ and Boletus edulis, Albatrellus ovinus, Ramaria flava and Lactarius trivialis by lyophilization (freeze drying). The samples of Boletus edulis and Albatrellus ovinus dried by different methods were obtained from various portions.

Flammulina velutipes, the mycelium of which was obtained from Japan and Pleurotus ostreatus were grown in the laboratory of the Foundation for Chemical Research and dried by lyophilization of the fresh material.

The dry matter of the mushrooms was determined by drying the samples finally at $105^{\circ} \mathrm{C}$ to constant weight. The sample was ashed in a quartz crucible with an 
electrical ash apparatus and after that in a muffle furnace for two hours at $500^{\circ} \mathrm{C}$. Total nitrogen was determined by a micro-Kjeldahl method and the protein content was calculated from Total $\mathrm{N} \times 6.25$. The amino acid contents were determined by hydrolysing mushroom powder in a closed ampoule with $6 \mathrm{~N}$ hydrochloric acid for $20 \mathrm{~h}$ at $105^{\circ} \mathrm{C}$. The determination was made using an automatic Amino Acid Analyzer, BioCal 201. Tryptophan was not determined. The free amino acids were determined as above from a $70 \%$ ethanol extract purified by an ion exchanger. The minerals were determined with Perkin-Elmer atomic absorption equipment according to the instructions (Analytical Methods for Atomic Absorption Spectrophotometry, Perkin-Elmer 1973).

\section{Results and discussion}

In Table 1 the basic composition of the mushrooms studied, and also that of egg, milk and potato for comparison are given. The Table also contains the analytical results of Kurkela (1972) on seven mushrooms and those of Aalto and Kreula (1972) on four mushrooms.

The protein content of the mushrooms varied between 12 and $31 \%$ of the dry material. The corresponding figures of Kurkela (1972) were 15-42\%, those of Aalto and Kreula (1972) $17-32 \%$ and those of Hattula (1969) given in her study of $196916-55 \%$. The protein content of the same mushroom species varied considerably according to the different studies. In the present work the protein content of Boletus edulis proved to be 22 and $23 \%$, whereas Aalto and Kreula (1972) obtained $32 \%$, Kurkela (1972) $37 \%$ and Hattula (1969) $34 \%$. In other respects the composition may be very much the same. The protein content of Cantharellus cibarius in the present work was $17 \%$, in the studies of Kurkela (1972) $15 \%$ and Aalto and Kreula (1972) $17 \%$.

The average ash content of the mushrooms in our study was $7.9 \%(5.7-12.8)$ of the dry material. In the other studies the corresponding figures were $8.1 \%(6-13)$ (Kurkela 1972), 8.1 \% (6.6- 8.8) (Aalto \& Kreula 1972) and 7.9\% $(5-11)$ (Hattula 1969).

The average fat content of the mushrooms calculated on a dry matter basis was $4.5 \%(1.2-8.9)$. In the other studies the corresponding figures were $3.1 \%(2-6)$ (Kurkela 1972) and $1.7 \%(1.4-2.1)$ (Aalto \& Kreula 1972). The basic composition of the cultivated mushrooms did not essentially differ from that of the wild mushrooms.

Table 2 shows the contents of the essential amino acids of mushrooms, egg, milk and potato, and the total number of the amino acids of the mushrooms as \% on a dry matter basis, including also other nitrogen-containing compounds, such as glucosamine. The content of glucosamine varied in different mushrooms between $0.2 \%$ and $8.6 \%$. The average contents of the essential amino acids of the mushrooms were closer to those of potato than egg and milk. The methionine content was lowest of all. Egg and milk contained larger amounts of all essential amino acids than the mushrooms. In various mushroom species the amounts of individual amino acids varied considerably: for example the lysine content between 0.4 and $1.5 \%$ and the leucine content between 0.5 and $1.4 \%$ of the dry material.

The total amount of the essential amino acids, excluding tryptophan, as it was not determined in this study, varied in the mushrooms between 2.6 and $7.6 \%$. In potato the corresponding figure was $3.1 \%$, in egg $21.8 \%$ and in milk $10.4 \%$. The amino acid contents of both wild and cultivated mushrooms corresponded relatively well to those given in the SFK food component table (Souci et al. 1969). The mushrooms contained $1.5 \%-3.5 \%$ free amino acids of the dry material.

Jandaik \& Kapoor (1976) have observed that although mushrooms, like most vegetables and fruit, contain plenty of water, they contain more protein in their dry material than vegetables and fruit.

Table 3 shows the fatty acid composition (\% w/w) of mushrooms, and for comparison also of egg, milk and

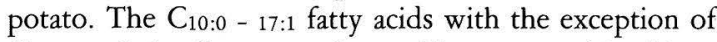
$\mathrm{C}_{16: 0}$, and the $\mathrm{C}_{20: 0}$ - 24:0 fatty acids were combined into two groups, since there was so little of them. The fatty acid composition of the mushrooms varied considerably, but resembled the general composition of vegetable fats in that the amounts of oleic and linoleic acids were comparatively large: the average figure for oleic acid was $33 \%(8-68)$ and for linoleic acid $42 \%(13-73)$ of the total amount of fatty acids. The result is in agreement with those obtained earlier by Aalto and Kreula (1972) and Shaw (1967). The fat content of the mushrooms was $0.2 \%-0.5 \%$, calculated on a wet weight basis. Therefore the composition of the fat is not significant from a nutritional point of view. In cultivating mushrooms the study of the composition of their fat may be important because the addition of fats to the substrate seems to accelerate the growth of mycelium and spore cases (Holtz \& Schisler 1971).

Table 4 gives the contents of calcium, iron, manganese, zinc and copper per $\mathrm{mg} / \mathrm{kg}$ dry material in the mushrooms and the contents of magnesium, sodium and potassium per $\mathrm{g} / \mathrm{kg}$ dry material. For comparison the table also gives the mineral contents of mushrooms found in the literature, and also the corresponding figures for egg, milk, potato and vegetables. The contents for vegetables were obtained by calculation from the figures given in the study of Koivistoinen et al. (1974). The mineral contents of the mushrooms studied were very much the same as given in the literature.

Compared with mushrooms the animal products egg and milk are poor sources of $\mathrm{Mn}$ and $\mathrm{Cu}$, and milk also of $\mathrm{Fe}$. Also the content of potassium was significantly 
Table 1. Basic composition of certain mushrooms, egg, milk and potato. * Indicates dry matter content of predried mushroom.

\begin{tabular}{|c|c|c|c|c|c|}
\hline \multirow{2}{*}{ Species and drying } & \multirow{2}{*}{$\begin{array}{c}\text { Dry material } \\
\%\end{array}$} & Protein & Fat & Ash & \multirow{2}{*}{ Reference } \\
\hline & & & 6 of $\mathrm{dm}$. & & \\
\hline \multicolumn{6}{|l|}{ Wild mushrooms } \\
\hline Boletus edulis $50-55^{\circ} \mathrm{C}$ & $91 *$ & 23 & 2.1 & 6.6 & \\
\hline$" \quad$ lyophil. & 95 * & 22 & 1.2 & 5.7 & \\
\hline$n$ & 10 & 37 & 2 & 8 & Kurkela 1972 \\
\hline$"$ & 8 & 32 & 1.6 & 8.2 & Aalto \& Kreula 1972 \\
\hline Albatrellus ovinus $50-55^{\circ} \mathrm{C}$ & 94 * & 12 & 7.1 & 7.0 & \\
\hline " lyophil. & $92 *$ & 12 & 4.6 & 6.0 & \\
\hline Ramaria flava " & 96 * & 24 & 2.0 & 6.0 & \\
\hline Lactarius trivialis & 93 * & 21 & 6.0 & 6.2 & \\
\hline " & 7 & 22 & 4 & 6 & Kurkela 1972 \\
\hline$"$ & 7 & 28 & 2.1 & 8.6 & Aalto \& Kreula 1972 \\
\hline Gyromitraesculenta $50-55^{\circ} \mathrm{C}$ & 92 * & 31 & 3.4 & 10.2 & \\
\hline Craterellus cornucopioides $50-55^{\circ} \mathrm{C}$ & 93 * & 17 & 4.9 & 10.4 & \\
\hline Cantharellus cibarius & $93 *$ & 17 & 3.9 & 12.8 & \\
\hline$"$ & 10 & 15 & 6 & 10 & Kurkela 1972 \\
\hline 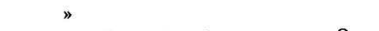 & 9 & 17 & 1.4 & 8.8 & Aalto \& Kreula 1972 \\
\hline Cantharellus tubaeformis $50-55^{\circ} \mathrm{C}$ & 90 * & 18 & 8.9 & 5.1 & \\
\hline Armillariella mellea & 93 * & 22 & 6.5 & 10.1 & \\
\hline Clitocybe nebularis & 12 & 38 & 2 & 6 & Kurkela 1972 \\
\hline Lactarius torminosus & 8 & 21 & 2 & 7 & $"$ \\
\hline " & 7 & 19 & 3 & 7 & $"$ \\
\hline " & 8 & 22 & 1.9 & 6.6 & Aalto \& Kreula 1972 \\
\hline Tricboloma nudum & 6 & 42 & 3 & 13 & Kurkela 1972 \\
\hline Boletus suillus & 6 & 22 & 3 & 8 & $"$ \\
\hline \multicolumn{6}{|l|}{ Cultivated mushrooms } \\
\hline Flammulina velutipes lyophil. & 16 & 29 & 5.3 & 8.7 & \\
\hline Pleurotus ostreatus " & 13 & 22 & 2.6 & 8.4 & \\
\hline Egg & 26 & 50 & 43 & 4 & Souci \& al. 1969 \\
\hline Milk & 13 & 24 & 29 & 5 & $"$ \\
\hline Potato & 22 & 9 & 0.7 & 6 & $"$ \\
\hline
\end{tabular}

Table 2. Contents of essential amino acids and their total amount as \% of dry matter in certain mushrooms, egg, milk and potato.

\begin{tabular}{|c|c|c|c|c|c|c|c|c|c|c|}
\hline Species and drying & Ile & Leu & Val & Met & Phe & Thr & Lys & Total & Try & $\begin{array}{c}\text { Total amount of } \\
\text { amino acids }\end{array}$ \\
\hline \multicolumn{11}{|l|}{ Wild mushrooms } \\
\hline Boletus edulis $50-55^{\circ} \mathrm{C}$ & 0.6 & 0.8 & 0.6 & 0.3 & 0.5 & 0.6 & 0.7 & 4.1 & - & 18.7 \\
\hline " lyophil. & 1.1 & 0.9 & 0.7 & 0.4 & 0.5 & 0.6 & 0.9 & 5.1 & - & 14.1 \\
\hline Albatrellus ovinus $50-55^{\circ} \mathrm{C}$ & 0.3 & 0.5 & 0.4 & 0.1 & 0.5 & 0.4 & 0.4 & 2.6 & - & 10.2 \\
\hline " lyophil. & 0.5 & 0.6 & 0.5 & 0.2 & 0.4 & 0.4 & 0.4 & 3.0 & - & 9.6 \\
\hline Ramariaflava " & 0.7 & 1.1 & 0.8 & 0 & 0.8 & 1.0 & 0.9 & 5.3 & - & 23.9 \\
\hline Lactarius trivialis & 1.1 & 1.3 & 1.0 & + & 0.9 & 0.9 & 0.8 & 6.0 & - & 17.6 \\
\hline Gyromitra esculenta $50-55^{\circ} \mathrm{C}$ & 1.1 & 1.6 & 1.4 & + & 1.1 & 1.0 & 1.4 & 7.6 & - & 25.0 \\
\hline Craterellus cornucopioides $50-55^{\circ} \mathrm{C}$ & 0.5 & 0.7 & 0.6 & + & 0.5 & 0.7 & 0.7 & 3.7 & - & 16.4 \\
\hline Cantbarellus cibarius & 0.5 & 0.8 & 0.6 & 0 & 0.5 & 0.5 & 0.7 & 3.6 & - & 10.6 \\
\hline Cantharellus tubaeformis & 0.5 & 0.7 & 0.6 & 0.1 & 0.5 & 0.6 & 0.7 & 3.7 & - & 15.4 \\
\hline Armillariella mellea & 0.8 & 1.3 & 0.9 & 0.4 & 0 & 0.9 & 0.9 & 5.2 & - & 19.4 \\
\hline \multicolumn{11}{|l|}{ Cultivated mushrooms } \\
\hline Flammulina velutipes lyophil. & 0.7 & 1.1 & 0.7 & 0.4 & 0.7 & 0.7 & 1.2 & 5.5 & - & 15.4 \\
\hline Pleurotus ostreatus & 0.9 & 1.4 & 1.0 & 0.3 & 0.9 & 0.9 & 1.5 & 6.9 & - & 19.4 \\
\hline Mean value & 0.7 & 1.0 & 0.7 & 0.2 & 0.6 & 0.7 & 0.9 & 4.8 & - & 16.6 \\
\hline \multicolumn{11}{|l|}{ SFK-data (Souci et al. 1969) } \\
\hline Boletus edulis & 0.3 & 1.1 & 0.7 & 0.5 & 0.9 & 1.0 & 1.7 & 6.2 & 1.9 & \\
\hline Lactarius deliciosus & 1.3 & 0.9 & 0.8 & 0.1 & 0.1 & 0.1 & 0.6 & 3.9 & + & \\
\hline Boletus rufescens & 0.3 & 0.9 & 0.4 & + & 0.6 & 0.7 & 0.4 & 3.3 & 0.2 & \\
\hline Boletus aurantiacus & 0.4 & 1.4 & 0.7 & 0.1 & 0.7 & 0.7 & 1.2 & 5.2 & 0.4 & \\
\hline Cantbarellus cibarius & 0.4 & 1.2 & 0.7 & 0.1 & 1.0 & 1.4 & 0.4 & 5.2 & 0.5 & \\
\hline Mean value & 0.5 & 1.1 & 0.7 & 0.1 & 0.7 & 0.8 & 0.9 & 4.8 & 0.7 & \\
\hline Egg & 3.5 & 4.2 & 4.0 & 2.6 & 2.9 & 2.0 & 2.6 & 21.8 & 0.7 & \\
\hline Milk & 1.5 & 2.4 & 1.7 & 0.6 & 1.2 & 1.1 & 1.9 & 10.4 & 0.3 & \\
\hline Potato & 0.5 & 0.6 & 0.5 & 0.2 & 0.4 & 0.4 & 0.5 & 3.1 & 0.1 & \\
\hline
\end{tabular}


Table 3. Fatty acid composition $(\% \mathrm{w} / \mathrm{w})$ in certain mushrooms, egg, milk and potato.

\begin{tabular}{|c|c|c|c|c|c|c|c|c|c|}
\hline Species and drying & C4:0-8:0 & $\mathrm{C}_{10: 0-17: 1^{*}}$ & $\mathrm{C}_{16: 0}$ & $\mathrm{C}_{18: 0}$ & $\mathrm{C}_{18: 1}$ & $\mathrm{C}_{18: 2}$ & $C_{18: 3}$ & $\mathrm{C}_{20: 0-24: 0}$ & Reference \\
\hline Wild mushrooms & & & & & & & & & \\
\hline Boletus edulis $50-55^{\circ} \mathrm{C}$ & & 3.3 & 11.5 & 1.1 & 16.9 & 62.7 & 2.4 & 1.9 & \\
\hline " lyophil. & & 3.6 & 8.8 & 0.8 & 13.3 & 62.5 & 3.9 & 7.3 & \\
\hline Albatrellus ovinus $50-55^{\circ} \mathrm{C}$ & & 5.8 & 6.8 & 2.0 & 32.0 & 52.5 & 0.4 & 0.8 & \\
\hline " lyophil & & 5.4 & 7.2 & 1.6 & 18.1 & 52.1 & 0.9 & 14.8 & \\
\hline Ramaria flava " & & 2.2 & 8.4 & 3.0 & 51.1 & 27.7 & 1.0 & 6.5 & \\
\hline Lactarius trivialis " & & 3.7 & 2.6 & 1.9 & 36.9 & 20.1 & 0.4 & $34.5 * *$ & \\
\hline Gyromitra esculenta $50-55^{\circ} \mathrm{C}$ & & 3.9 & 13.1 & - & 8.1 & 72.9 & 0.5 & 1.6 & \\
\hline Craterellus cormucopioides $50-55^{\circ} \mathrm{C}$ & & 3.2 & 6.6 & 5.4 & 67.9 & 12.6 & 2.1 & 3.4 & \\
\hline Cantharellus cibarius " & & 4.8 & 9.1 & 3.8 & 41.2 & 37.0 & 1.2 & 3.0 & \\
\hline "tubaeformis " & & 2.3 & 15.3 & 1.6 & 56.4 & 19.2 & 2.0 & 3.3 & \\
\hline Armillariella mellea " & & 9.8 & 10.9 & 1.9 & 43.2 & 32.9 & 0.4 & 0.9 & \\
\hline Cultivated mushrooms & & & & & & & & & \\
\hline Flammulina velutipes lyophil. & & 5.9 & 11.4 & 10.0 & 31.6 & 39.0 & 0.8 & 1.2 & \\
\hline Pleurotus ostreatus & & 2.7 & 14.3 & 1.7 & 14.8 & 60.6 & 0.7 & 5.1 & \\
\hline Mean value & & 4.4 & 9.7 & 2.9 & 33.2 & 42.5 & 1.3 & 6.5 & \\
\hline Literature data & & & & & & & & & \\
\hline Agaricus campestris & & 6.4 & 11.9 & 5.5 & 2.6 & 63.4 & - & 9.0 & Shaw 1967 \\
\hline Amanita muscaria & & 3.5 & 10.1 & 8.0 & 39.6 & 52.7 & - & - & $"$ \\
\hline Tricboloma nudum & & 1.5 & 25.4 & 9.5 & 33.0 & 29.5 & 1.1 & - & \\
\hline Mean value & & 3.8 & 15.8 & 7.7 & 25.1 & 48.5 & & & \\
\hline Egg & & 3.7 & 22.2 & 7.7 & 36.8 & 11.2 & 0.3 & 1.2 & Posati \& al. 197 \\
\hline Milk & 5.9 & 24.8 & 25.3 & 9.2 & 30.9 & 3.6 & - & 2.6 & Ammon 1968 \\
\hline$"$ & 8.3 & 21.3 & 25.1 & 10.0 & 23.1 & 3.0 & 1.0 & - & Antila 1974 \\
\hline Potato & & - & 18.7 & 4.3 & 0.7 & 47.7 & 28.5 & - & Lepage 1968 \\
\hline
\end{tabular}

Table 4. Contents of $\mathrm{Ca}, \mathrm{Fe}, \mathrm{Mn}, \mathrm{Zn}$ and $\mathrm{Cu}(\mathrm{mg} / \mathrm{kg}$ dry matter) and contents of $\mathrm{Mg}, \mathrm{Na}$ and $\mathrm{K}$ ( $\mathrm{g} / \mathrm{kg}$ dry matter) in certain mushrooms. For comparison the corresponding figures (mean value) of egg, milk, potato and 17 vegetables are given.

\begin{tabular}{|c|c|c|c|c|c|c|c|c|c|}
\hline \multirow{2}{*}{ Species and drying } & $\mathrm{Ca}$ & $\mathrm{Fe}$ & $\mathrm{Mn}$ & $\mathrm{Zn}$ & $\mathrm{Cu}$ & $\mathrm{Mg}$ & $\mathrm{Na}$ & $\mathrm{K}$ & \multirow{2}{*}{ Reference } \\
\hline & \multicolumn{5}{|c|}{$\mathrm{mg} / \mathrm{kg}$} & \multicolumn{3}{|c|}{$\mathrm{g} / \mathrm{kg}$} & \\
\hline Boletus edulis $50-55^{\circ} \mathrm{C}$ & 120 & 49 & 18 & 72 & 24 & 0.5 & 1.0 & 29 & \\
\hline " lyophil. & 180 & 99 & 14 & 100 & 26 & 0.5 & 0.8 & 23 & \\
\hline Albatrellus ovinus $50-55^{\circ} \mathrm{C}$ & 110 & 50 & 11 & 55 & 18 & 0.7 & 0.6 & 33 & \\
\hline " lyophil. & 93 & 47 & 9 & 38 & 13 & 0.8 & 0.4 & 30 & \\
\hline Ramaria flava & 670 & 100 & 72 & 89 & 34 & 1.3 & 0.7 & 23 & \\
\hline Lactarius trivialis & 130 & 57 & 15 & 76 & 25 & 1.1 & 0.8 & 23 & \\
\hline Gyromitra esculenta $50-55^{\circ} \mathrm{C}$ & 120 & 140 & 26 & 110 & 85 & 1.0 & 0.8 & 44 & \\
\hline Craterellus cornucopioides $50-55^{\circ} \mathrm{C}$ & 280 & 79 & 64 & 130 & 35 & 1.0 & 0.9 & 52 & \\
\hline Cantharelluscibarius " & 220 & 93 & 29 & 110 & 46 & 1.1 & 0.6 & 53 & \\
\hline "tubaeformis & 280 & 120 & 65 & 61 & 34 & 0.5 & 0.9 & 41 & \\
\hline Armillariella mellea & 79 & 110 & 21 & 88 & 26 & 1.5 & 0.5 & 53 & \\
\hline Mean value & 207 & 86 & 31 & 84 & 33 & 0.9 & 0.7 & 37 & \\
\hline Literature data & & & & & & & & & \\
\hline Boletus edulis & 110 & 56 & 9 & 130 & 67 & 1.0 & - & - & Hinneri 1975 \\
\hline " & - & 32 & 12 & 182 & 21 & 0.6 & - & - & Sassi pers.comm. \\
\hline " & - & 52 & 11 & - & 49 & - & - & - & Kurkela 1972 \\
\hline Albatrellus ovinus & - & 25 & 9 & 40 & 3 & 0.6 & - & - & Sassi pers.comm. \\
\hline Ramaria flava & - & 51 & 20 & 109 & 46 & 0.9 & - & - & P \\
\hline Lactarius trivialis & - & 40 & 19 & 151 & 28 & 1.2 & - & - & " \\
\hline$"$ & - & 33 & 13 & - & 26 & - & - & - & Kurkela 1972 \\
\hline Gyromitra esculenta & - & 181 & 29 & 97 & 93 & 1.0 & - & - & Sassi pers.comm. \\
\hline Craterellus cornucopioides & 850 & 78 & 12 & 52 & 15 & 1.0 & - & - & Hinneri 1975 \\
\hline Cantharellus cibarius & 140 & 76 & 11 & 200 & 35 & 0.9 & - & - & $"$ \\
\hline$"$ & - & 67 & 30 & 96 & 23 & 1.1 & - & - & Sassi pers.comm. \\
\hline$"$ & - & 78 & 31 & - & 43 & - & - & - & Kurkela 1972 \\
\hline Mean value & 367 & 64 & 17 & 117 & 37 & 0.9 & & & \\
\hline Egg & 2154 & 81 & 1 & 52 & 5 & 0.5 & 5.5 & 6 & Souci \& al. 1969 \\
\hline Milk & 9846 & 11 & 1 & 27 & 2 & 1.3 & 3.6 & 12 & » \\
\hline Potato & 591 & 41 & 7 & 1 & 7 & 1.5 & 0.9 & 24 & \\
\hline Mean value of 17 vegetables & 3308 & 51 & 37 & 38 & 6 & 1.8 & - & 25 & Koivistoinen \& al. 1974 \\
\hline
\end{tabular}


smaller in animal products than in mushrooms. On the other hand the contents of calcium and sodium were many times greater in animal products than in mushrooms. When comparing the average mineral contents of 17 vegetables with the corresponding contents of mushrooms, it is observed that there are no detectable differences in the contents of potassium, iron and magnanese in the dry material. In contrast, the calcium content of the vegetables was about tenfold and that of magnesium twofold compared with those of mushrooms. In mushrooms, however, the content of zinc was twofold and that of copper about fivefold compared with the corresponding contents in vegetables.

The mushrooms analysed in the present study, with the exception of the cultivated ones, were collected from around Tampere, those of Sassi (personal communication) from eastern Finland and those of Hinneri (1975) from the islands of south-western Finland. Taking this into consideration the results obtained in the different studies concerning the mineral contents of mushrooms were rather similar (Hinneri 1975, Kurkela 1972, Sassi pers. comm.).

Mushrooms are palatable and cheap material to be used to supplement basic food. As with other vegetable products also, mushrooms add to the amount of watersoluble nutrients in the diet. However, the variation in the yield of mushrooms in different years from the very heavy to the almost insignificant limits the effective use of mushrooms as a raw material for the food industry.

In order to ensure all-year-round processing it would be important to study in greater detail the possibilities of producing also other species than Agaricus by cultivation.

\section{References}

Aalto, A. \& Kreula, M. 1972: Eräiden metsäsienten aminohappoja rasvahappokoostumuksesta. - Karjantuote 55: 264-265.

Ammon, R. 1968: Ernährungsphysiologische Aspekte der Milchverzehrs. - In: Die Bedeutung der Milch für die Gesundheit des Menschen. Deutsche Gesellschaft für Ernährung, Frankfurt a.M. 71 p.

Antila, V. 1974: Ravintorasvojen koostumuksesta. - In: Ravintorasvat, Symp., Valtion ravitsemusneuvottelukunnan julkaisu 2: 16-28.

Hattula, M. L. 1969: Sienet valkuaisaineiden lähteenä. - Kotitalous 33: 16-19.

Hinneri, S. 1975: Mineral elemets of macrofungi in oak-rich forests on Lenholm Island, inner archipelago of SW Finland. - Ann. Bot. Fennici 12: 135-140.

Holtz, R. B. \& Schisler, L. C. 1971: Lipid metabolism of Agaricus bisporus (Lange) Sing. I. Analysis of sporophore and mycelial lipids. - Lipids 6: 176-180.

Jandaik, C. L. \& Kapoor, J. N. 1976: Amino acid composition of mushroom Pleurotus sajor-caju (Fr.) Singer. - Mushroom J. 41: 154-156.

Koivistoinen, P., Ahlström, A., Varo, P. \& Nissinen, H. 1974: Mineral element composition of Finnish vegetables, fruits and berries. - Acta Agr. Scand. 24: 131-134.

Kurkela, R. 1972: Metsäsienet - haaste maamme elintarviketeollisuudelle ja ravintotutkimukselle. - Kemian Teollisuus 11: 825-829.

Lepage, M. 1968: The lipid components of white potato tubers (Solanum tuberosum). - Lipids 3: 477-481.

Lintzel, W. 1943: Über den Nährwert des Eiweisses essbarer Pilze. - Z. Lebensmittel-Unters. Forsch. 86: 162-163.

Nieminen, L. 1976: The Nephrotoxicity of Cortinarius speciosissimus gathered in Finland. An experimental study in the rat. - Dissertation, Res. Center/Lääke-Medipolar, Turku. $33 \mathrm{p}$.

Posati, L., Kinsella, J. F. \& Watt, B. K. 1975: Comprehensive evaluation of fatty acids in foods. - J. Am. Dietet. Assn. 67: 111-115.

Shaw, R. 1967: Fatty acid of fruiting bodies of Basidiomycetes. Nature 213: 86-87.

Souci, S. W., Fachmann, W. \& Kraut, H. 1969: Die Zusammensetzung der Lebensmittel. II. - Wissenschaftliche Verlagsgesellschaft M.B.H., Stuttgart.

Rautavaara, T. 1947: Suomen sienisato. - 534 p. Porvoo.

Accepted for publication

on 8 November 1976 